\title{
The Eastern Canadian Arctic at ca. 6 ka BP: A Time of Transition
}

\section{L'est de l'Arctique canadien à $6 \mathrm{ka} \mathrm{BP}$, une période de transition \\ Die ostkanadische Arktis um etwa 6 ka: Eine Übergangs-periode}

\author{
Kerstin M. Williams, Susan K. Short, John T. Andrews, Anne E. Jennings, \\ William N. Mode et James P.M. Syvitski
}

Volume 49, numéro 1, 1995

La paléogéographie et la paléoécologie d’il y a 6000 ans BP au Canada Paleogeography and Paleoecology of 6000 yr BP in Canada

URI : https://id.erudit.org/iderudit/033026ar

DOI : https://doi.org/10.7202/033026ar

Aller au sommaire du numéro

Éditeur(s)

Les Presses de l'Université de Montréal

ISSN

0705-7199 (imprimé)

1492-143X (numérique)

Découvrir la revue

Citer cet article

Williams, K. M., Short, S. K., Andrews, J. T., Jennings, A. E., Mode, W. N. \& Syvitski, J. P. (1995). The Eastern Canadian Arctic at ca. 6 ka BP: A Time of Transition. Géographie physique et Quaternaire, 49(1), 13-27.

https://doi.org/10.7202/033026ar

\section{Résumé de l'article}

L'Holocène moyen a été une période de transition bien déterminée dans l'est de l'Arctique canadien. Selon de nombreux indicateurs (pollen, diatomées, foraminifères, mollusques et taux de sédimentation côtiers), il semble qu'un maximum thermique ait été atteint vers le milieu de l'Holocène (6-4 ka), plusieurs milliers d'années après le maximum d'insolation - un retard dû à l'inertie thermique causée par la présence de l'immense inlandsis. Les données terrestres démontrent qu'un réchauffement s'est amorcé vers $6 \mathrm{ka}$, à la fois dans le subarctique (Labrador, Ungava) et dans l'île de Baffin. Les données marines, d'autre part, indiquent qu'il y a eu des changements de structure de l'eau vers $6 \mathrm{ka}$ à la fois dans le nord-est de l'Arctique canadien et le long de la côte du Groenland avec des indices de températures maximales marines de surface à $8 \mathrm{ka}$. Nous posons l'hypothèse selon laquelle les changements de circulation marine, à la fois le long de l'île de Baffin et le long de la côte est du Groenland ont été provoqués par le relèvement isostatique des chenaux arctiques. Avec l'arrêt de l'écoulement (plus chaud) en provenance de l'Atlantique et la diminution du cubage d'eau provenant des grandes profondeurs de l'océan Arctique dans les chenaux arctiques, l'évacuation par les détroits de Fram et du Danemark s'est accrue et la colonne d'eau s'est modifiée. Les changements de concentration et de durée de la glace marine le long de la côte est du Canada auraient eu d'importantes répercussions sur les écosystèmes marins côtiers et terrestres.
Tous droits réservés (C) Les Presses de l'Université de Montréal, 1995

Ce document est protégé par la loi sur le droit d'auteur. L'utilisation des services d'Érudit (y compris la reproduction) est assujettie à sa politique d'utilisation que vous pouvez consulter en ligne.

https://apropos.erudit.org/fr/usagers/politique-dutilisation/ 


\section{THE EASTERN CANADIAN ARCTIC AT CA. 6 KA BP : A TIME OF TRANSITION*}

Kerstin M. WILLIAMS', Susan K. SHORT', John T. ANDREWS ${ }^{1,2}$, Anne E. JENNINGS ${ }^{1,2}$, William N. MODE ${ }^{3}$, and James P.M. SYVITSKI ${ }^{4}$ : Institute of Arctic and Alpine Research, and ${ }^{2}$ Department of Geological Sciences, University of Colorado, Boulder, Colorado 80309, U.S.A.; ${ }^{3}$ Department. of Geology, University of Wisconsin at Oshkosh, Oshkosh, Wisconsin, 54901, U.S.A., ${ }^{4}$ EMG/Atlantic Geoscience Centre, Geological Survey of Canada, Bedford Institute of Oceanography, Box 1006, Dartmouth, Nova Scotia B2Y 4A2.

ABSTRACT The middle Holocene was a time of definite environmental transition in the Eastern Canadian Arctic. Based on several proxy indicators (pollen, diatoms, foraminifera, molluscs and nearshore sedimentation rates), it appears that a thermal maximum occurred around middle Holocene (6-4 ka), several thousand years after the insolation maximum - a lag caused by the thermal inertia of the earlier massive ice sheet. Terrestrial records indicate that a warming began around $6 \mathrm{ka}$, both in the subarctic (Labrador - Ungava) and on Baffin Island. Marine records, on the other hand, suggested major water structure changes around 6 ka both in the Northeastern Canadian Arctic and also along the East Greenland coast with evidence of a marine surface water temperature maximum at $8 \mathrm{ka}$. We hypothesize that the marine circulation changes, both along the Baffin Island and along the East Greenland coasts, were primarily driven by glacio-isostatic uplift of the Arctic Channels. With the cessation of water flow of Atlantic (warmer) origin, and decrease in water volume from the deeper parts of the Arctic Ocean through the Arctic Channels, the export through the Fram and Denmark straits increased and the water column changed. Changes in the concentration and duration of sea ice along the eastern Canadian coast would have had important repercussions on the biota of the coastal marine and terrestrial ecosystems.
RÉSUMÉ L'est de l'Arctique canadien à 6 ka BP, une période de transition. L'Holocène moyen a été une période de transition bien déterminée dans l'est de l'Arctique canadien. Selon de nombreux indicateurs (pollen, diatomées, foraminifères, mollusques et taux de sédimentation côtiers), il semble qu'un maximum thermique ait été atteint vers le milieu de l'Holocène (6-4 ka), plusieurs milliers d'années après le maximum d'insolation - un retard dû à l'inertie thermique causée par la présence de l'immense inlandsis. Les données terrestres démontrent qu'un réchauffement s'est amorçé vers $6 \mathrm{ka}$, à la fois dans le subarctique (Labrador, Ungava) et dans l'île de Baffin. Les données marines, d'autre part, indiquent qu'il y a eu des changements de structure de l'eau vers 6 ka à la fois dans le nord-est de l'Arctique canadien et le long de la côte du Groenland avec des indices de températures maximales marines de surface à $8 \mathrm{ka}$. Nous posons l'hypothèse selon laquelle les changements de circulation marine, à la fois le long de l'île de Baffin et le long de la côte est du Groenland ont été provoqués par le relèvement isostatique des chenaux arctiques. Avec l'arrêt de l'écoulement (plus chaud) en provenance de l'Atlantique et la diminution du cubage d'eau provenant des grandes profondeurs de l'océan Arctique dans les chenaux arctiques, l'évacuation par les détroits de Fram et du Danemark s'est accrue et la colonne d'eau s'est modifiée. Les changements de concentration et de durée de la glace marine le long de la côte est du Canada auraient eu d'importantes répercussions sur les écosystèmes marins côtiers et terrestres.
ZUMMENFASSUNG Die ostkanadische Arktis um etwa 6 ka: Eine Übergangsperiode. Das mittlere Holozän war eine eindeutige Umwelt-Übergangszeit in der ostkanadischen Arktis. Gestützt auf zahlreiche Indikatoren (Pollen, Kieselalgen, Foraminiferen, Mollusken und die Sedimentations-rate am Ufer) scheint es, $\mathrm{da} \beta$ ein thermales Maximum um die Mitte des Holozäns erreicht wurde (6-4 ka), mehrere tausend Jahre nach dem Sonneneinstrahlungsmaximum - eine Verzögerung, welche durch die thermale Trägheit der früheren massiven Eisdecke bewirkt wurde. Belege zu Land zeigen, daß eine Erwärmung um 6 ka begann, sowohl in der Subarktis (Labrador-Ungava) wie auch auf der Baffin-Insel. Meeresbelege andererseits weisen auf bedeutende Wasserstruktur-Änderungen um $6 \mathrm{ka}$, sowohl in der nordöstlichen kanadischen Arktis wie auch entlang der Küste von OstGrönland, mit Anhaltspunkten für maximale Wassertemperaturen an der Meeresoberfläche um 8 ka. Wir stellen die Hypothese auf, daß die Wechsel der marinen Zirkulation, sowohl entlang der Baffin-Insel wie auch der Küsten von Ost-Grönland, in erster Linie durch die glazial-isostatische Anhebung der arktischen Kanäle hervorgerufen wurden. Mit der Beendigung des (wärmeren) Wasserflusses vom Atlantik und der Abnahme des Wasservolumes von den tieferen Teilen des arktischen Ozeans durch die arktischen Kanäle nahm die Ausfuhr durch die Meeregen von Fram und Dänemark zu, und die Wassersäule änderte sich. Die Wechsel in der Konzentration und Dauer des Meereises entlang der ostkanadischen Küste sollen bedeutende Auswirkungen auf Ökosysteme an der Meeresküste und zu Land gehabt haben.

Manuscrit reçu le 8 mai 1994 ; manuscrit révisé accepté le 2 décembre 1994

* PALE Contribution No. 17; Geological Survey of Canada Contribution No. 38994 


\section{INTRODUCTION}

Our area of interest, the Eastern Canadian Arctic, excluding the Queen Elizabeth Islands, at $6 \mathrm{ka}$ (all dates are ${ }^{14} \mathrm{C}$ years, BP) was undergoing a transition from recent deglaciation to the "modern" arctic environment. At $10 \mathrm{ka}$ most of the region was covered by ice of the Laurentide Ice Sheet and deglaciation was relatively slow between 10 and $8 \mathrm{ka}$. At about 8 ka Hudson Strait and Hudson Bay were extensively deglaciated. To the north, however, Foxe Basin was not deglaciated until $6.7 \mathrm{ka}$. By 6 ka residual ice persisted over Labrador and Ungava, and a substantial ice cap lay across Baffin Island (Dyke and Prest, 1987; Andrews, 1989).

Compared to the dynamic times of the last glaciation and deglaciation, the ca. 6 ka time slice has been thought of as a period when 'not much happened', because major changes in boundary conditions were not occurring globally. But it is a time when we have beginning detailed historical (archeological) records available (Far- and Near East, as well as Labrador), against which we can compare global climate models and paleo-reconstructions.

However, the middle Holocene appears to have been a time of definite environmental change in our research area. The sensitivity of the different environmental variables to perturbation is uncertain at best. Environmental change must have affected the entire northern hemisphere both directly via the ocean circulation system and indirectly by feedback-induced mechanisms. The terrestrial and marine records all indicate that, although major boundary changes may not have taken place, the approximately 6 ka time slice was a period of transition in the Northern Canadian Arctic as well as along the East Greenland Coast. The Eastern Canadian Arctic is very sensitive to small changes in summer temperature (Williams and Bradley, 1985) and possibly other variables as well such as duration of sea ice, and changes in cyclone paths. Each new time increment is dependent on the initial conditions resulting from the previous one; thus even minor perturbations could, in the course of several iterations, produce a sizeable change.

We define our area of coverage as the "Eastern Canadian Arctic" which for the purposes of this paper extends from the forest-tundra ecotone in northern Labrador-Ungava to the area of Jones Sound ( $\mathrm{ca} .56^{\circ}$ to $72^{\circ} \mathrm{N}$ ), and from the coast of eastern Baffin Island and Labrador to the eastern shores of Foxe Basin and northern Hudson Bay. Background information of the present environmental variables that control floral and faunal distributions are discussed by Jacobs et al. (1985). We also compare the timing of ocean circulation changes in Baffin Bay and Davis Strait with those along the East Greenland coast.

\section{ENVIRONMENT}

\section{CLIMATE}

Baffin Island is a climatically sensitive area because 1) it is an elongated north-south trending region which possesses steep climatic and environmental gradients both latitudinally and altitudinally (from coast to hinterland) and 2) summer temperature is close to freezing, depending on location. Thus a small change in temperature may produce a large difference in both glacial and sea ice extent. July temperatures vary from $\mathrm{ca} .10^{\circ} \mathrm{C}$ at tree-line in Labrador Ungava to $<0^{\circ} \mathrm{C}$ in the accumulation zones of the various ice caps and glaciers at elevations between 700 and 2000 $\mathrm{m}$ asl (Andrews and Miller, 1972). Climatically the area can be considered as a unit, although it can be broken down into several sub-regions (Maxwell, 1981; Jacobs et al., 1985). Baffin Island exhibits the following temperature and precipitation characteristics:

Mean annual temperature range: $26-33^{\circ} \mathrm{C}$

July mean daily temp.: $3-8^{\circ} \mathrm{C}$

January mean daily temp.: -20 to $-33^{\circ} \mathrm{C}$

Annual precipitation : $200-500 \mathrm{~mm}, 25-50 \%$ falls as rain

\section{OCEAN CIRCULATION}

The primary currents in Baffin Bay and Davis Strait flow counter clockwise northward along the Greenland coast, turning south along the Baffin Island coast (Fig. 1). The Arctic Ocean surface water enters the region through numerous channels to the north. The sills (ca. 400-500 m) in those channels control what layer of water from the Arctic Ocean will enter Baffin Bay. The Baffinland Current (ca. 0 $2^{\circ} \mathrm{C} ; 30-31 \%$ s salinity, summer) flows along the Baffin Island coast and, depending on the strength of the current at any given time, may reach all the way down to the shelf floor.

The West Greenland Current runs northward along the West Greenland shelf. It transports both cold, arctic water from the East Greenland Current, and a deeper component from the Atlantic water. The East Greenland Current flows around the southernmost tip of Greenland (where it changes name to the West Greenland Current) and up along the west Greenland coast. This body of water extends to the shelf floor. The West Greenland Current surface water, during its progress northward, has a surface temperature in summer of $\mathrm{ca} .4^{\circ} \mathrm{C}$ and salinity of ca. $32-34 \%$ during summer. Parts of this current are continually deflected westward during its way north (Fig. 1). The warmer and more saline (i.e. heavier) water sinks underneath the Arctic water in the Baffinland Current to the west. In times of stronger West Greenland Current flow, the transport of warmer water increases and impinges on the Baffin Island shelf. If the Baffinland Current weakens and/or the West Greenland Current intensifies, we may see changes in the bottom water, not only on the shelf, but in the deeper parts of the fjords as well.

About $70 \%$ of the total surface water outflow from the Arctic Ocean occurs through the Fram and Denmark Straits (along the east coast of Greenland); the remainder flows through the Canadian Arctic channels. If one component of this export system changes, so does the other. In fact, if the intensity of the Gulf Stream varies, it will influence both the heat transport and volume of water into and out of the Arctic Ocean. 
FIGURE 1. Location map with ocean circulation.

Localisation et courants océaniques.

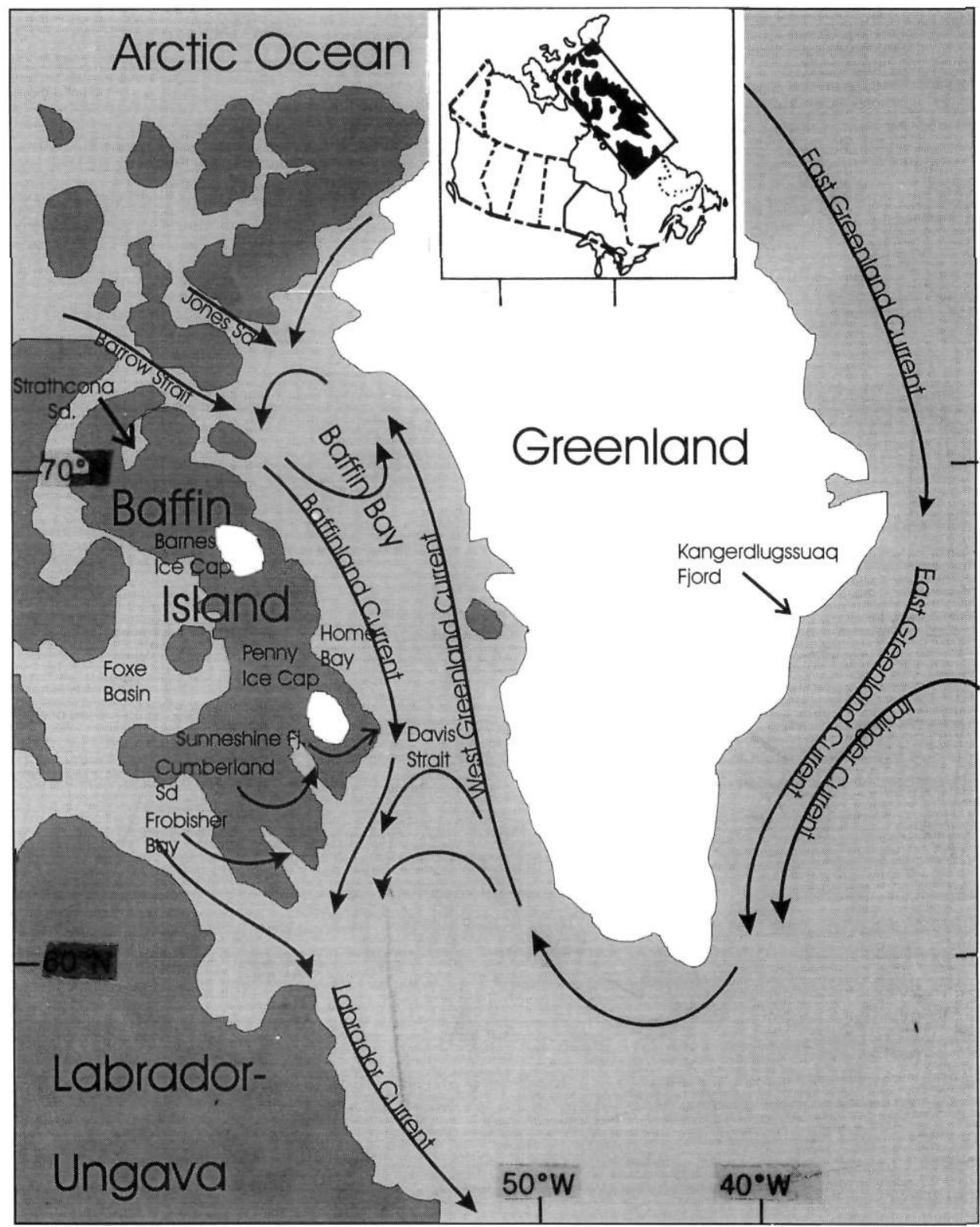

\section{TEMPORAL COVERAGE}

The 6 ka interval falls in the "Kangilo" chronozone ( 8 to $5 \mathrm{ka}$ ) for the Eastern Canadian Arctic (Andrews, 1982). It is important to note that there is a difference between radiocarbon years and sidereal years (Bard et al., 1993). There is also a potential difference between dates on terrestrial materials and marine carbonates (shells and foraminifera) (Stuiver and Braziunas, 1993). Shell dates require a correction for the apparent age of sea water, which we assume to be around $450 \pm 50 \mathrm{yrs}$. These issues are illustrated in the following: two samples, one on terrestrial plant remains and one on marine carbonates, have been processed through the program CALIB (3.03) (Stuiver and Reimer, 1993). The laboratory-quoted date on the plants is taken as $6000 \mathrm{BP} \pm$ $100 \mathrm{BP}$, whereas the date on shells, normalized to $-25 \%$ 。 $\partial{ }^{13} \mathrm{C}$, is $6450 \pm 100 \mathrm{BP}$. At the $95 \%$ confidence level, the calendar age of the plant sample varies between 6570 and
7165 years, whereas the shell sample has an age between 6670 and 7170 years. We report dates in ${ }^{14} \mathrm{C}$ years.

It must be noted that radiocarbon dates on molluscs from the Geological Survey of Canada are reported normalized to $0 \% \circ \partial{ }^{13} \mathrm{C}$; thus they do not require an ocean reservoir correction.

\section{GLACIAL AND RELATIVE SEA LEVEL}

The extent of glacial ice in the Eastern Canadian Arctic underwent a major change between 7 and $5 \mathrm{ka}$. The most dramatic event occurred about 6700 BP when Foxe Basin was almost instantaneously deglaciated (Dyke, 1974; Andrews, 1987; Dyke and Prest, 1987). Thereafter the remnants of the Laurentide Ice Sheet over North America were largely confined to Baffin Island. By 6 ka the remnant ice sheet (Fig. 2) was located along the axis of the island and 

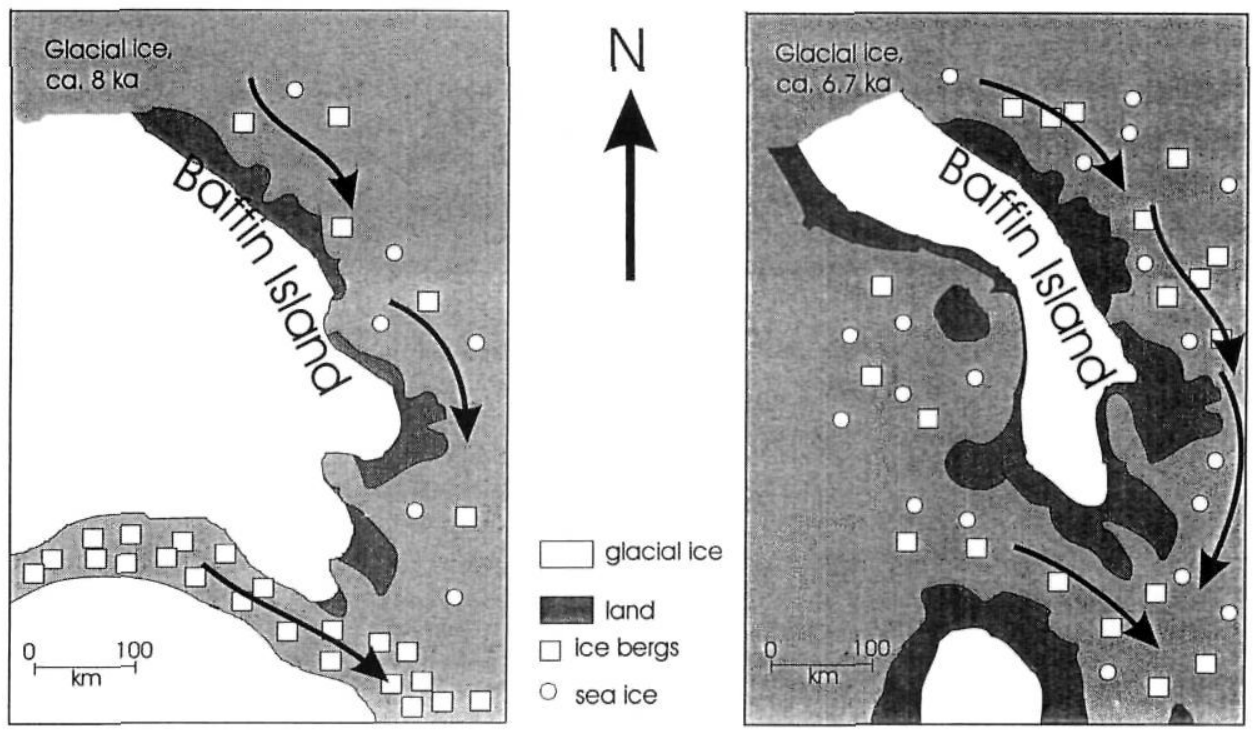

FIGURE 2. Glacial extent at $c a$ 8 and $6.7 \mathrm{ka}$ in Baffin Island and Labrador (adapted from Andrews, 1985).

Recouvrement glaciaire vers $8 \mathrm{ka}$ et 6,7 $\mathrm{ka}$ à l'île de Baffin et au Labrador (adapté de Andrews, 1985). most fjords along the eastern coast were deglaciated. However, late deglaciation ( $<6 \mathrm{ka}$ ) characterized a portion of Home Bay and to the west the ice lay ca. $50 \mathrm{~km}$ east of the present coast. Retreat of the remnant ice sheet has occurred over the last $6 \mathrm{ka}$, but it has been punctuated by intervals of ice advance.

Most of the present land surface of Baffin Island was deglaciated only after $8 \mathrm{ka}$. Between 8 and 6.7 the ice sheet was still massive (Fig. 2). After $6.7 \mathrm{ka}$, the remnant ice sheet was split into two or possibly three major parts. The largest extended from northern Baffin Island southward to near the Penny Ice Cap (Fig. 1). The area of the Penny Ice Cap was a separate ice mass, whereas the third remnant was located between Frobisher Bay and Foxe Basin. The combined area of the three ice sheet parts at $6 \mathrm{ka}$ was probably close to $81,000 \mathrm{~km}^{2}$ or about $20 \%$ of the area of Baffin Island (Dyke, 1974). Hence we might expect that both physical and biological systems were still in a state of transition around $6 \mathrm{ka}$ (Abbott, 1991; Miller, 1992).

Relative sea level was mostly higher than present with a strong west to east gradient (Dyke, 1974; Quinlan, 1985; Andrews and Peltier, 1989 ) in the present elevation of the 6 ka shoreline. It is probable that a few areas along the extreme outer east coast, particularly eastern Cumberland Sound, have witnessed a rise of relative sea level over the last $6 \mathrm{ka}$. The maximum change of sea level over the last 6 ka was $80-100 \mathrm{~m}$ with the area of maximum postglacial land emergence located along the eastern coast of Foxe Basin. The zero isobase is not well defined but may run close to the outer east coast and cross the Cumberland Peninsula (Andrews, 1980; Quinlan, 1985). Certainly at the present time there is considerable evidence that much of the outermost east coast is undergoing submergence whereas emergence is dominant over the western area of Baffin Island and at the heads of the major bays and fjords (Andrews, 1980). Thus in coastal and fjord regions seaward of the 0 isobase, water depths would have increased by up to $20 \mathrm{~m}$ over the last $6 \mathrm{ka}$.

\section{NEARSHORE SEDIMENTATION RATES}

Arctic fjord basins, by their nature of being over-deepened, provide an ideal locale for the uninterrupted accumulation of sediment. Fjords receive sediment principally from drainage of the alpine hinterland including glacifluvial discharge. Delivery mechanisms include: (1) bedload dumping at river mouths, (2) hemipelagic sedimentation from the seasonal surface layer, (3) turbidity currents generated from prodelta failure, (4) diffusive processes (slides, wave action and tidal currents) that transport nearshore sediment into deeper water, and locally (5) rafting by sea ice and icebergs and (6) aeolian transport from erosion of exposed sandur surfaces.

Sediments collected from pocket-basins located distal to a river mouth often receive sediment solely by hemipelagic sedimentation, with occasional contributions of coarsergrained sediment via turbidity currents (Syvitski and Hein, 1991). This simplified sediment delivery allows variations in the content of organic carbon, within cores collected from distal parts of arctic fjord basins, to be used as a proxy indicator of sediment accumulation rates (Syvitski et al., 1990).

Most of the flux of carbon to the seafloor of Baffin Island fjords is a result of primary productivity of phytoplankton within the seasonal surface layer during the summer and fall season (Syvitski et al., 1990). Furthermore, the flux of particulate organic carbon (POC) through the surface waters can be considered relatively constant over the length of an arctic fjord basin. POC settles rapidly through the water column in association with the river-borne sediment and in the form of phytodetritus and marine snow (Winters and Syvitski, 1992). Thus POC in the water column shows an inverse exponential relationship with the concentration of the inorganic suspended sediment, a direct result of inorganic dilution (Syvitski et al., 1990: Fig. 1C).

The organic carbon $(\mathrm{OC})$ content preserved within a sediment column relates to past changes in the vertical flux 
of POC to the seafloor, the dilution effect of sedimenting lithogenic particles and the degradation of labile carbon. There is little evidence of post-oxic degradation of organic carbon within the Baffin fjord sediment column (Syvitski et al., 1990), possibly related to the anoxic zone close to the sediment-water interface. Primary phytoplankton $(\mathrm{OC})$ production, averaged over some years, might vary by no more than a factor of two, even given occasional extreme changes in water properties. Thus the time-history of $\mathrm{OC}$ burial within Baffin fjord basins appears to depend largely on the rate of inorganic sediment delivery during the Holocene (Andrews, 1990).

The OC stratigraphy of long cores collected from Baffin fjords show a consistent carbon stratigraphy (Syvitski et al., 1990; Short et al., 1994). The middle to late Holocene sections of cores contain relatively high OC values, with early Holocene sediments displaying much lower values. Core SU5, collected from the outer part of Sunneshine Fiord in $146 \mathrm{~m}$ of water, shows this typical OC stratigraphy (Fig. 3A). The OC values can then be converted to a proxy of inorganic sediment accumulation, with the explicit assumption that the buried OC signal is derived wholly from a constant flux of marine carbon deposited uniformly throughout the fjord. To predict accumulation rates, the relationship between sediment accumulation and $O C$ content is first determined (Fig. 3B), and then applied to the downcore carbon signal to predict a high-resolution record of sediment accumulation rates (Fig. $3 C$ ).

The Holocene transition from high to low sediment accumulation rates is ca. $7 \mathrm{ka}$, based on 17 dates that border this transition on six cores (CL5, MC4.1, IT2.3, TI3, MA2,
SU5). When we consider that all of these Baffin fjords are dominated by surface melt from large ice fields, the change in accumulation rates can be interpreted to reflect paleotemperature conditions, with periods of high accumulation representing warming conditions and rising ELAs (equilibrium line alttitude) (see Syvitski and Andrews, 1994, for arguments). Thus in our interpretation based on OC stratigraphy, the early Holocene is a period of warm alpine climate, high turbid river discharge. The middle Holocene was a period of cool alpine temperatures bracketing the 6 ka transition, whereas the late Holocene was a period of colder, more variable conditions.

\section{MOLLUSCS}

The present distribution of marine bivalves and gastropods is relatively well known. In terms of establishing any differences between the $6 \mathrm{ka}$ world and today the key indicator species are those that have shown biogeographical changes that can be associated with changes in environmental factors. A strong NNE-SSW marine faunal boundary runs from southern Baffin Island to NW Greenland (Fig. 4). It reflects the "front" between the relatively warm waters of the West Greenland and Irminger Currents and the cold polar waters entrained in the Baffinland Current. Subarctic species can survive east and south of this boundary but are typically absent to the north and west. "Warm" extra-limital molluscs have been collected and dated from raised marine sediments along the outer east coast of Baffin Island. There is little evidence so far for any equivalent episodes along the coastline of Foxe Basin.

\section{SUNNESHINE CORE 5}

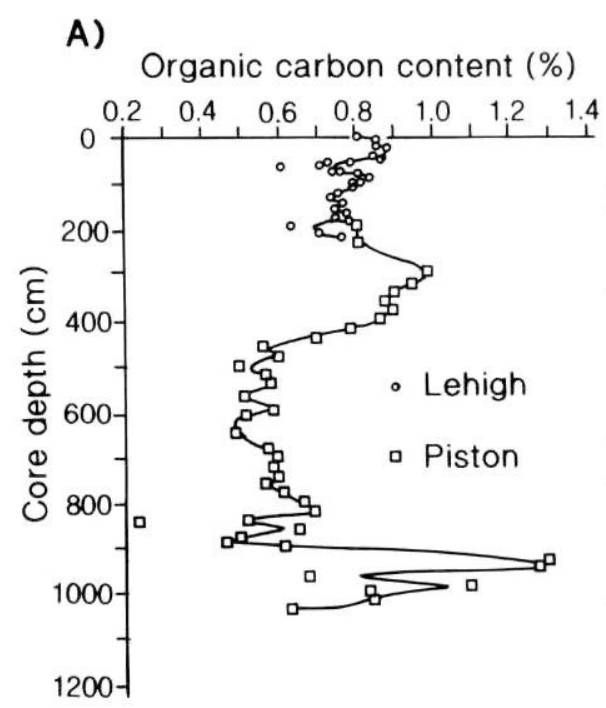

B)

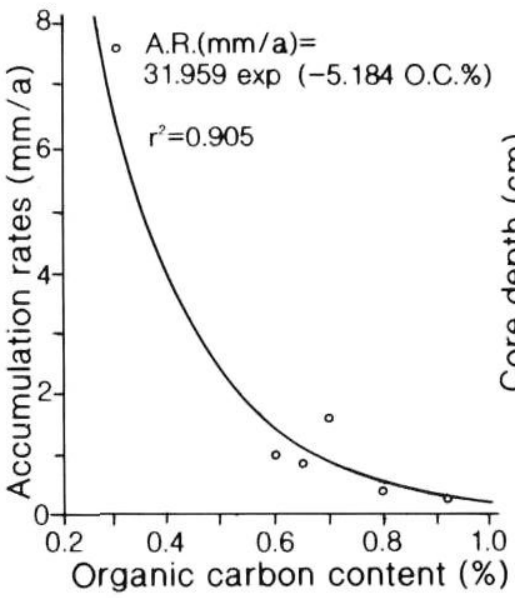

C) Accumulation rates $(\mathrm{mm} / \mathrm{a})$

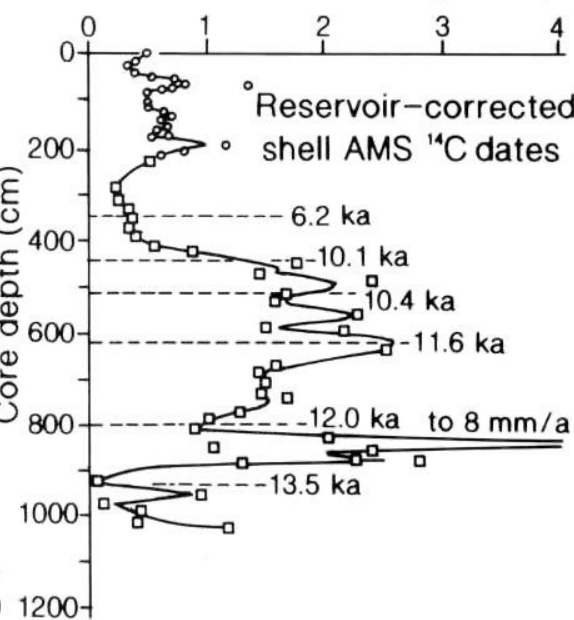

FIGURE 3. Sunneshine Core 5. Organic carbon content plotted against $(A)$ core depth and $(B)$ against accumulation rates for Sunneshine Fjord core SU5. Several more ${ }^{14} \mathrm{C}$ dates have been obtained from this core, and they fall on the curve between 0.3 and $0.6 \%$ (Andrews et al., 1994). (C) Accumulation rates vs. core depth for SU5. Note that piston core is displaced $1.7 \mathrm{~m}$ down in relation to Lehigh based on Huntec record. For location of Sunneshine Fjord (SU5) see Figure 1.
Forage du Sunneshine Core 5. A. Teneur en carbone organique par rapport à la profondeur $(A)$ et par rapport au taux d'accumulation $(B)$. Plusieurs autres dates au radiocarbone ont été obtenues de ce forage et se situent entre 0,3 et 0,6\% sur la courbe de la teneur (Andrews et al., 1994). C. Taux d'accumulation par rapport à la profondeur de SU5 (voir la localiation à la fig. 1). 


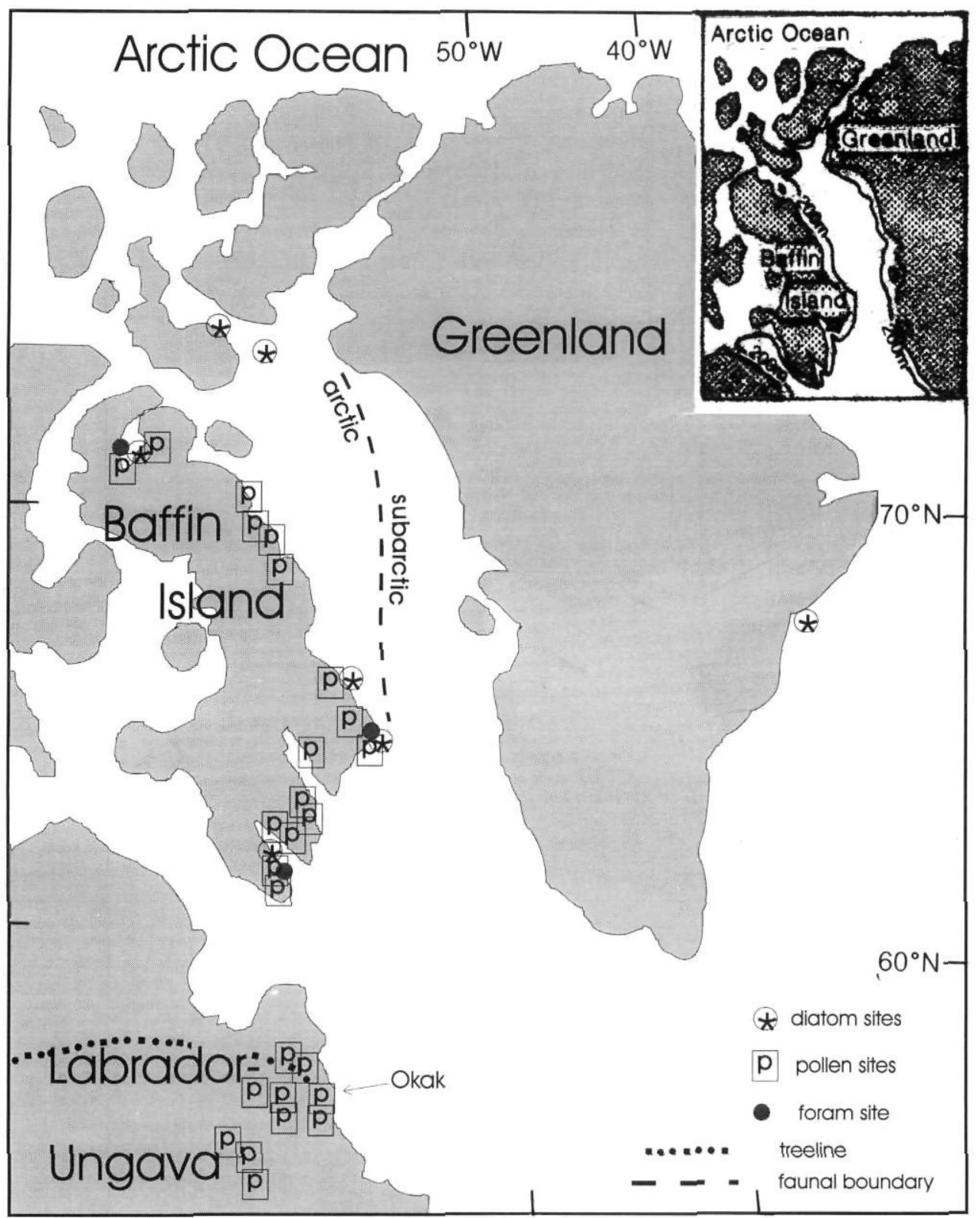

FIGURE 4. Map of faunal boundaries (Andrews, 1972), treeline, diatom, pollen and foraminifera sites. Insert map showing generalized $200 \mathrm{~m}$ bathymetric contour.

Limites fauniques (Andrews, 1972), limites des arbres, sites de diatomées, sites de foraminifères et sites polliniques. Le carton montre la courbe bathymétrique de $200 \mathrm{~m}$.

One indicator species of note is the common blue mussel, Mytilus edulis, which today occurs along the west coast of Greenland but is only rarely present along the east coast of Baffin Island. The oldest date from a site bearing $M$. edulis is ca. $8 \mathrm{ka}$ in east-central Baffin Island, and the youngest date, from Home Bay, is ca. 3 ka (Andrews, 1972). The other critical species is the Iceland scallop, Chlamys islandicus, which today can be found in the modified Atlantic water at depths below $200 \mathrm{~m}$ in Cumberland Sound, but which is rare elsewhere (Andrews, 1972; Lubinsky, 1972). The earliest date from this species is around 9 ka from Frobisher Bay (Miller, 1980), but it was plentiful within the eastern Baffin Island fjords at $8 \mathrm{ka}$.

The extra-limital species generally occur along the midto northern coastline of eastern Baffin Island. There are no reports of fossil Mytilus edulis from Frobisher Bay. Thus we infer that the source for the spread of these molluscs was increased advection of Atlantic Water in Baffin Bay associated with the West Greenland Current. The influx of $M$. edulis along the east coast of Baffin Island is essentially correlative with the first occurrences of boreal molluscs in both East and West Greenland (Funder and Weidick, 1991). Thus from the viewpoint of molluscs the major changes occurred prior to and post- $6 \mathrm{ka}$.

\section{POLLEN}

\section{LABRADOR-UNGAVA}

Thirteen lake sites from northeastern Labrador-Ungava analyzed at the INSTAAR Palynology Laboratory in the 1970's and 1980's are summarized here (Short and Nichols, 1977; Short 1978a, b; Stravers, 1981; Clark et al., 1989; Short, unpublished data). There is a strong coastal bias (Fig. 4) in these lake records, but three sites are located in 


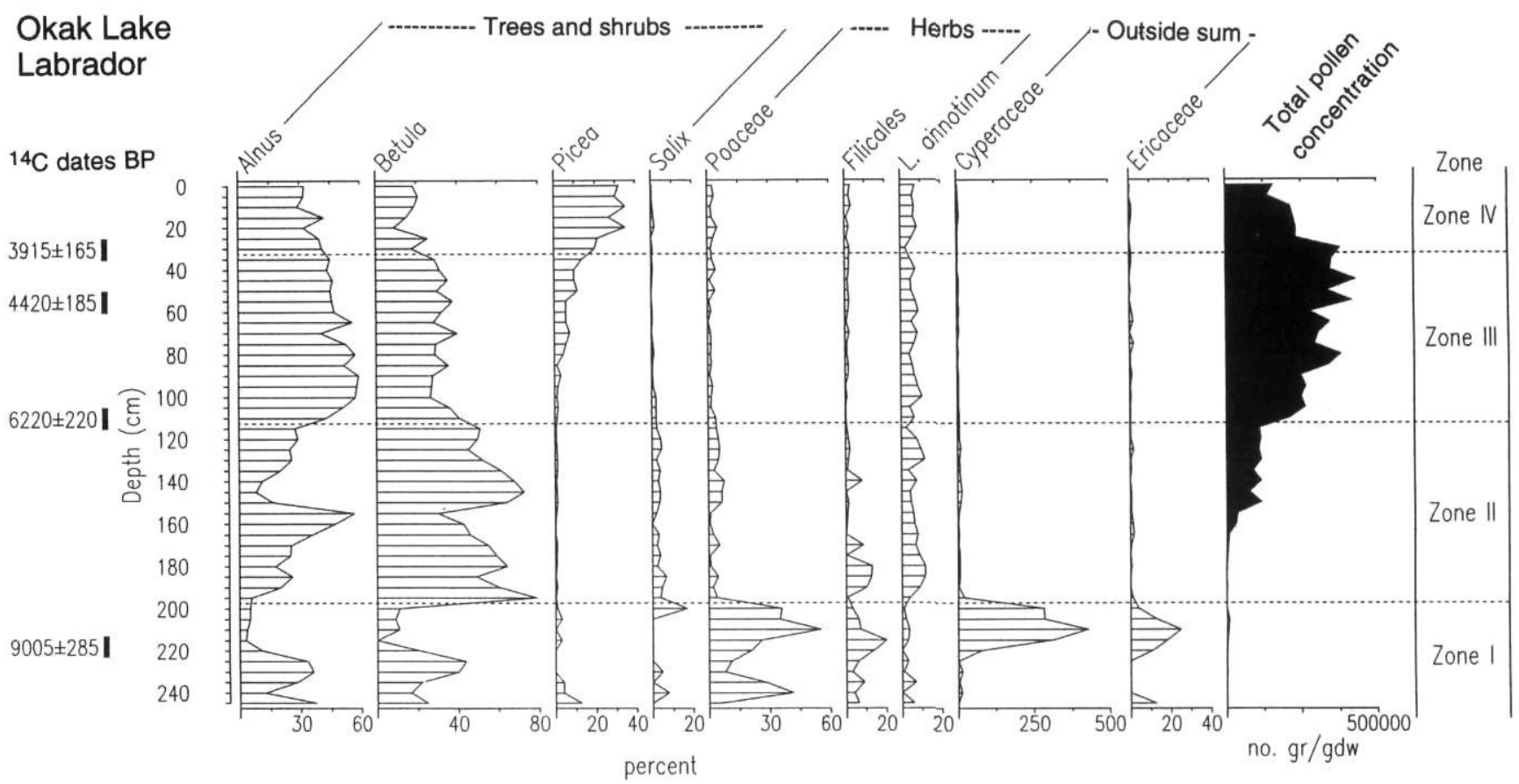

FIGURE 5. Percentage pollen diagram (reduced taxa) and summary pollen concentration curve, Okak Lake, Labrador.

the interior of the peninsula and three sites are located close to the maximum height of land (continental divide). The pollen record from Okak Lake $\left(57^{\circ} 23^{\prime} \mathrm{N}, 62^{\circ} 07^{\prime} \mathrm{W}\right.$ ) (Short, unpublished data) is used here to summarize the vegetation and climate record from pollen spectra in this region (Fig. 5). Four pollen zones can be defined for the majority of the Labrador-Ungava lake sites:

\begin{tabular}{|c|c|c|}
\hline & $10-8.5 \mathrm{ka}$ or $6.7 \mathrm{ka}$ & Graminoid Tundra \\
\hline & 8.5-6.7 ka & $\begin{array}{l}\text { Birch Tundra; not registered in } \\
\text { all sites }\end{array}$ \\
\hline & & Alder-Birch Shrub Tundra \\
\hline & ent & Spruce Woodland \\
\hline
\end{tabular}

The 6 ka chronozone falls within the transition from low arctic tundra to an alder-birch shrub tundra vegetation. This is a productive period, marked by increased sedimentation rates and high pollen concentration values in all LabradorUngava lake sites. The correlative timing at both coastal and northern interior sites (6.8-6.4 ka) reflects a major regional warming at the 6 ka time period.

Transfer function equations are used to quantify the pollen-climate association, thus enabling fossil pollen spectra to be transferred into climatic variables. They are important in interpreting arctic pollen diagrams becasue of the scarcity of detailed studies of pollen-vegetation relationships. Transfer function studies show a high statistical association between the modern pollen percentages and summer climatic parameters for northern Canada. The assumptions, methodologies, and problems in the application of transfer functions to pollen data are discussed in Andrews et al. $(1980,1981)$ and Diaz (1985) (see also Imbrie and Kipp,1971, Webb and Bryson, 1972, and Kay and Andrews,
Diagramme de pourcentages polliniques (nombre réduit de taxons) et courbe abrégée de concentration pollinique (Okak Lake, Labrador).

1983 , for discussions of the technique). Standard errors on the residuals of the formulae used in this paper are $\leqslant 1^{\circ} \mathrm{C}$.

July temperatures $\left({ }^{\circ} \mathrm{C}\right)$, based on formulae published in Andrews et al. (1980, 1981) and Diaz (1985), have been calculated for five northern Labrador-Ungava sites (Short and Nichols, 1977; Short, 1978b, unpublished data) and presented in Figure 6 . The data record warming July temperatures after ca. $8 \mathrm{ka}$; this pattern increases at 7 to $6 \mathrm{ka}$. This configuration is responding primarily to the importance of Alnus (alder) in the pollen spectra at this time. Note that the higher temperature estimates in the early Holocene are an artifact of high Alnus and Betula (birch) percentages at the base of pollen diagrams (e.g., Okak Lake, Fig. 5) because of low, local pollen productivity during Zone I.

Diaz compared the characteristic anomaly patterns of modern surface temperature and precipitation to tree-ring indices $(0-300 \mathrm{yr})$ and fossil pollen $(0-6000 \mathrm{yr})$ variations in northern North America (Diaz, 1985; Diaz et al., 1989). Regression equations were derived from a set of 153 modern pollen sites across Alaska and Canada and were used to estimate temperature and precipitation from 39 fossil pollen sites from about $6000 \mathrm{BP}$ to the present. His analyses of 17 lake sites record conditions warming from $6.6 \mathrm{ka}$ with maximum July temperatures $\left(+1.5-2^{\circ} \mathrm{C}\right)$ between 6 and 3 ka (Fig. 7 a, b).

\section{BAFFIN ISLAND}

The pollen sites summarized here comprise marine cores (6), lake cores (15) and peat sections (3) (Fig. 5) (Davis, 1980; Mode, 1980; Mudie and Short, 1985; Short et al., 1985; Short et al., 1989; Mode and Jacobs, 1987). There is again a bias toward coastal sites, and the majority are 


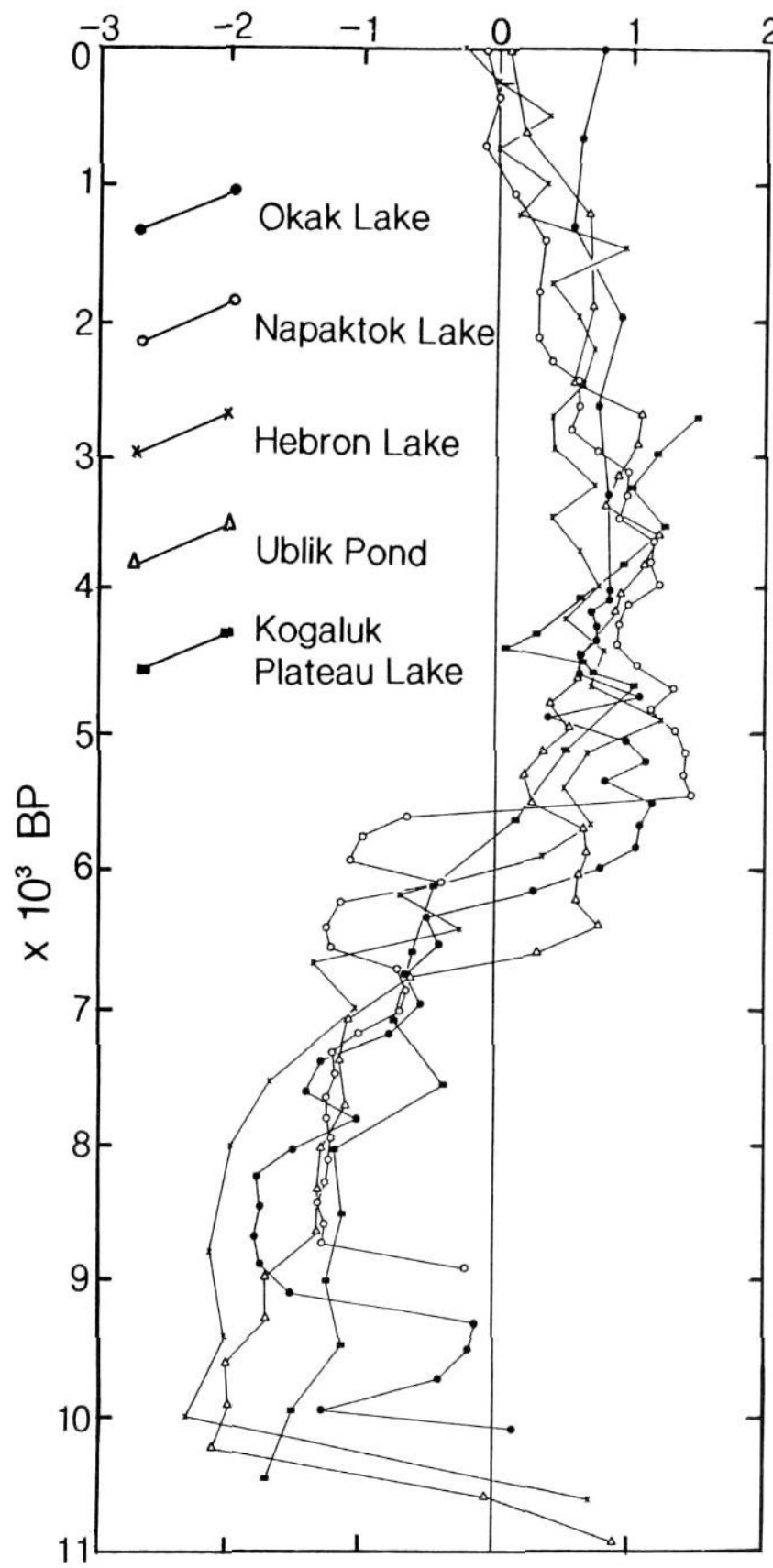

FIGURE 6. Time-series of estimated July temperatures at five sites in Labrador. Temperatures expressed as relative departures from the smoothed mean. July $\mathrm{T}\left({ }^{\circ} \mathrm{C}\right)=6.69+0.149$ Alnus +0.083 Picea - 0.016 Salix - 0.017 Poaceae.

Chronologie des températures estimées de juillet, à cinq sites du Labrador. Les températures sont exprimées en termes de déviations relativement à la moyenne régularisée. Températures de juillet $=6,69+0,149$ Alnus $+0,083$ Picea $-0,016$ Salix $-0,017$ Poaceae.

located at low elevations. The local climatic optimum in the pollen records from Baffin Island sites is often marked by increased shrub (birch, willow, heaths) percentages, minimum grass percentages, and high exotic influx. By $6 \mathrm{ka}$, birch percentages were rising or had peaked, replacing, in part, willow percentages which had peaked earlier. The expansion of shrub birch populations in Baffin Island indicates conditions warmer than present at $6 \mathrm{ka}$. A middle late Holocene trend to more severe conditions is observed in many Baffin Island sites, usually marked by a change from a diverse, shrub-dominated assemblage to a more impoverished graminoid spectrum. Short et al. (1985) state that nearly all the records of that time suggest that climate started to cool sometime between 5 and $2.5 \mathrm{ka}$.

The upper pollen zones of the fiord cores are reasonably representative of the regional pollen rain. The dating of this zone boundary is not well constrained however, and varies between 9 and 4 ka (Mudie and Short, 1985; Short et al., 1989). At least one marine core, HU77-159 (Mudie and Short, 1985), shows a middle Holocene peak in birch percentages resembling that of the lake sediment cores. A striking feature of five eastern Baffin Island marine cores is the peak in Dinoflagellates that occurs ca. $4.5 \mathrm{ka}$. This peak was perhaps caused by the warming of the surface ocean, as this event coincides with the postglacial marine climatic optimum (5-3 ka) in the Eastern Canadian Arctic (Andrews, 1972).

The published quantitative data set from Baffin Island is small, two lake and three peat sites, and does not include recently complete lake sediment analyses. Diaz et al. (1989) record higher July temperatures from the beginning of their analyses at $6 \mathrm{ka}$ to around $3 \mathrm{ka}$, followed by a decline thereafter of about $1^{\circ} \mathrm{C}$ (Fig. $7 \mathrm{C}$ ).

\section{BENTHIC FORAMINIFERA}

Benthic foraminifera have been used to infer bottom water mass changes on the Baffin Island shelf. Recent work by Hunt and Corliss (1993) supports earlier work of Vilks (1969) that the benthic foraminiferal assemblages in the Archipelago are related to the Arctic and Atlantic water masses. Arctic water supports agglutinated assemblages and Atlantic water supports calcareous assemblages. Based on core records along the Baffin Island continental shelf, there was a major change in bottom water characteristics during the middle to late Holocene.

The chronology of these events is based on ${ }^{14} \mathrm{C}$ dating. Some of the records were obtained prior to the advent of AMS (accelerator mass spectroscopy) methods of dating (Scott Inlet, Cape Aston and some Frobisher Bay dates). Because of low carbonate in some of those cores, conventional dates (sometimes requiring as much as $20 \mathrm{~cm}$ of core sediment) on disseminated organic matter form the basis of the chronology. However, shell dates were available on some of the earlier cores (e.g. Sunneshine Fiord). Records from Barrow Strait, Strathcona Sound and Cumberland Sound are based on AMS dates on carbonate.

\section{BARROW STRAIT AND STRATHCONA SOUND}

From the end of deglaciation to ca. 2-4 ka, calcareous foraminifera indicate that Atlantic water occupied the seafloor at both sites (Fig. 8) (Vilks et al., 1989; Short et al., 1994). Vilks et al. (1969) inferred that the sills in the western archipelago were deeper due to isostatic loading and the Atlantic water from the Arctic Ocean flowed into the 

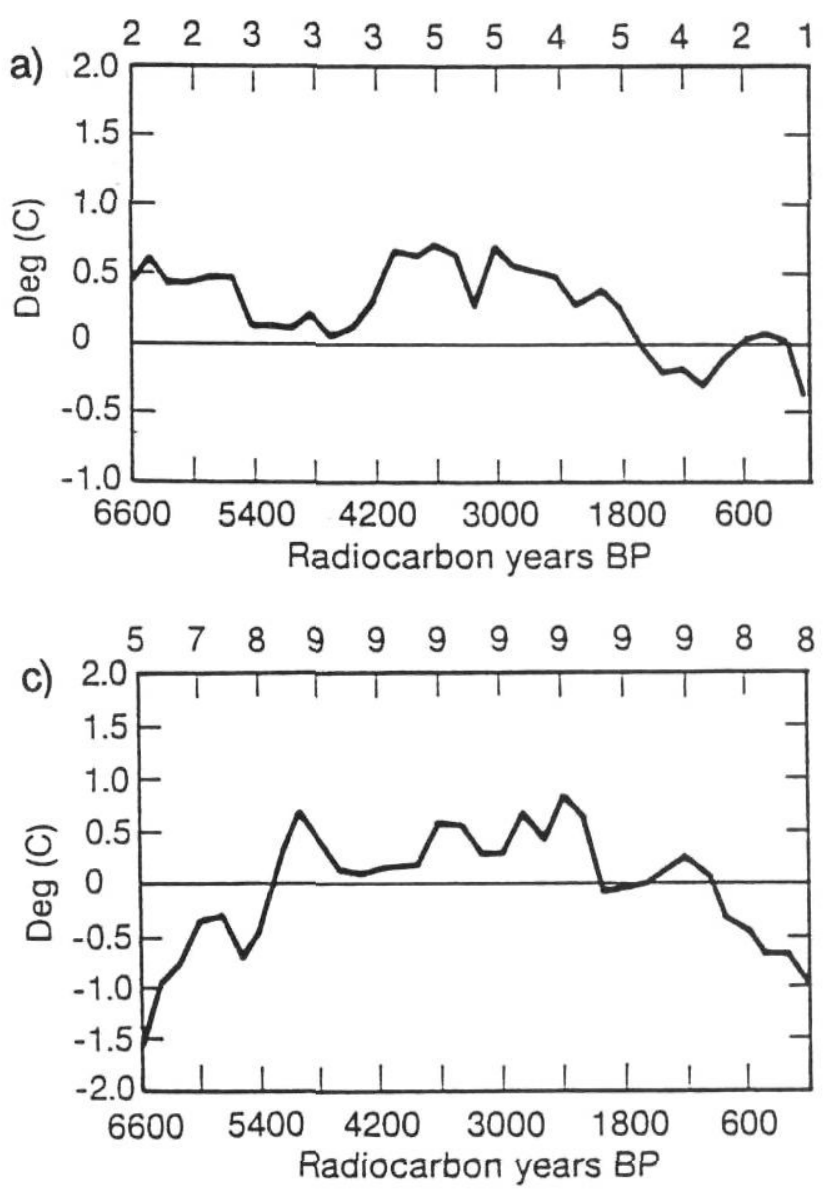

channels. By 2 to $4 \mathrm{ka}$, the sills had risen sufficiently to impede inflow of the Atlantic layer. The timing of critical emergence is based on AMS dates on mosses (upper) and foraminifera (lower) in the Strathcona Sound core. The Barrow Strait core has a date of $7990( \pm 70)$ (MacLean et al., 1989) from the postglacial part of the record.

\section{SCOTT INLET AND CAPE ASTON}

Four cores from this area (Scott Inlet, Cape Aston and Home Bay, off Narpaing Fiord) indicate that the calcareous zone is displaced by the arenaceous zone around $6 \mathrm{ka}$ (Fig. 8). This transition was interpreted by Osterman and Nelson (1989) to indicate that the Baffinland Current was initiated and the Atlantic water, which had previously occupied the shelf, was displaced offshore as a result of critical emergence of the Arctic Channels (e.g. England, 1976).

\section{SUNNESHINE FIORD AND CUMBERLAND SOUND}

Foraminiferal zonations suggest an onset of the Baffinland Current around $5 \mathrm{ka}$, when the arenaceous foraminifera replace the calcareous (Andrews et al., 1984). This allowed arctic water to extend from the surface to the sea floor (Jennings, 1989)

\section{FROBISHER BAY}

The arenaceous zone was established by 2 ka, considerably later than anywhere else along the coast (Fig. 8).

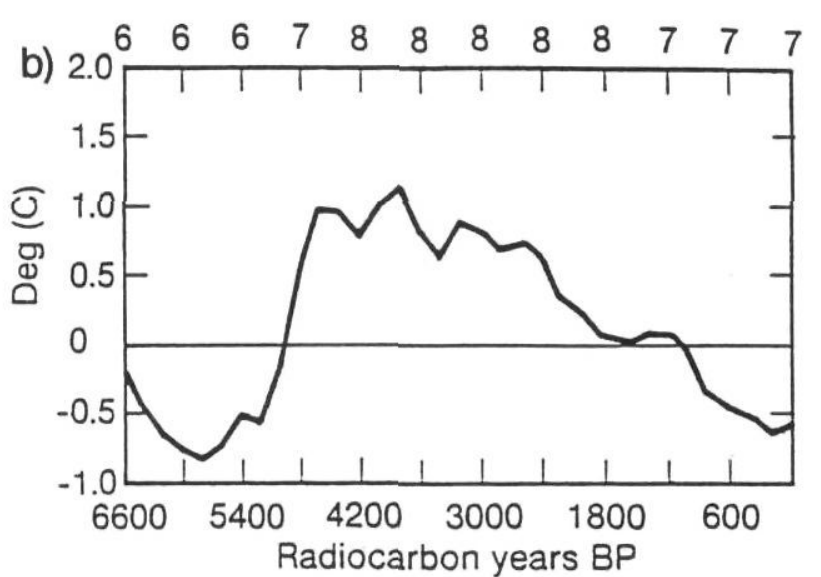

FIGURE 7. Time-series plot of reconstructed July temperature departures from the $6600 \mathrm{BP}$ value; a) Labrador, b) Québec, c) Baffin Island. Numbers on top of each graph indicate number of sites available at each $200 \mathrm{yr}$ interval (from Diaz et al., 1989: Fig. 7).

Chronologie des températures de juillet reconstituée à partir de 6600 BP. a) Labrador; b) Québec; c) île de Baffin. Les chiffres audessus des différentes courbes donnent le nombre de sites disponibles à chacun des intervalles de 200 ans (de Diaz et al., 1989, fig. 7).

The Nonion labradoricum zone at ca. 6 ka was attributed by Osterman (1984) to the onset of the Baffinland Current and Labrador Current.

The above records suggest that the shelf was influenced by Atlantic water both from the West Greenland Current and from the Atlantic layer in the Arctic Ocean prior to $6 \mathrm{ka}$ along the eastern Baffin Island coast, and prior to about 2-4 $\mathrm{ka}$ in the western Arctic Archipelago. After ca. $6 \mathrm{ka}$, emergence of the Arctic archipelago inhibited much of the flow of the Atlantic layer from the Arctic Ocean. Arctic surface water flowed along the shelf, displacing the Atlantic water of the West Greenland Current offshore.

\section{DIATOMS}

The diatom records are used as proxy indicators of the true surface water conditions (upper $50 \mathrm{~m}$ or less), which are more easily influenced by seasonal warming or cooling. The increase in productivity, as seen in the diatom flux to the bottom sediments, has been used as proxy indicators for increased temperature and/or decreased ice duration.

The lacustrine record from Square Lake, Labrador, was found to suggest a period or increased productivity (warming) from approximately $8 \mathrm{ka}$ to about $6 \mathrm{ka}$, after which a gradual productivity decrease (cooling) took place (Fig. 9) (Clark et al., 1989). A similar lake record was reported by Lemmen et al. (1988) from Cuberland Peninsula, Baffin 


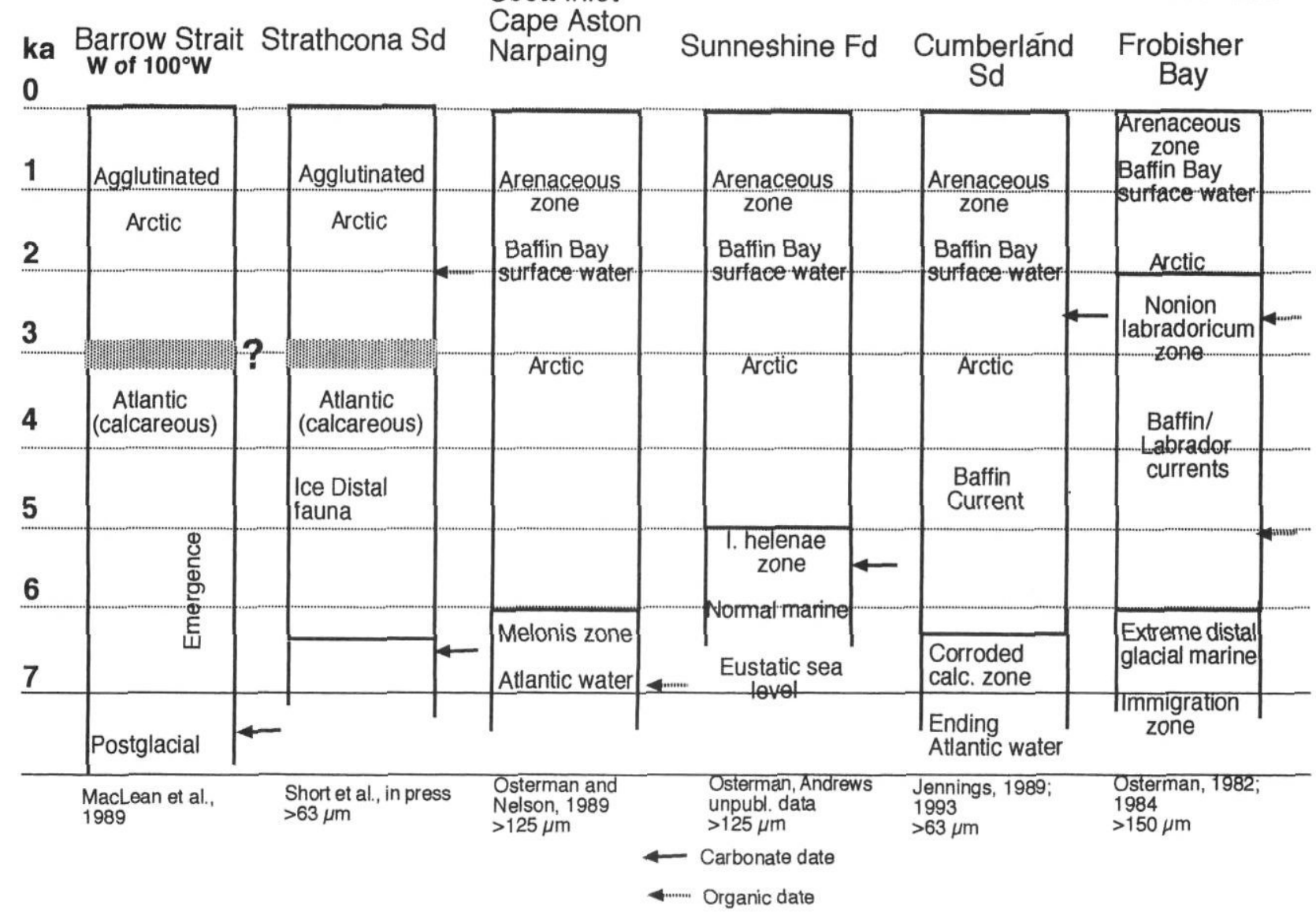

FIGURE 8. Foraminiferal sites showing transitions from calcareous to arenaceous fauna.

Stratigraphie des sites de foraminifères montrant le passage de faune calcaire à faune arénacée.

\section{SURFACE WATER INDICATORS -- DIATOMS}

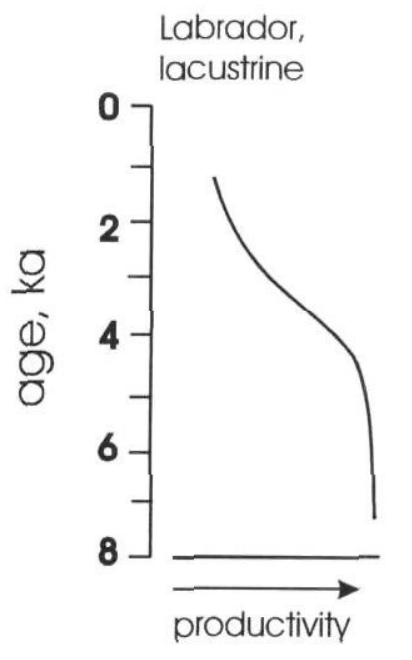

cooling warming

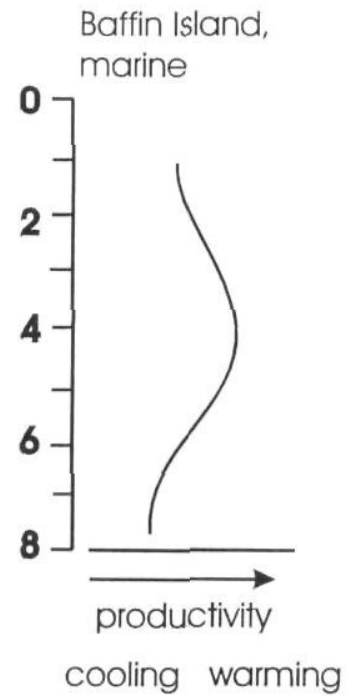

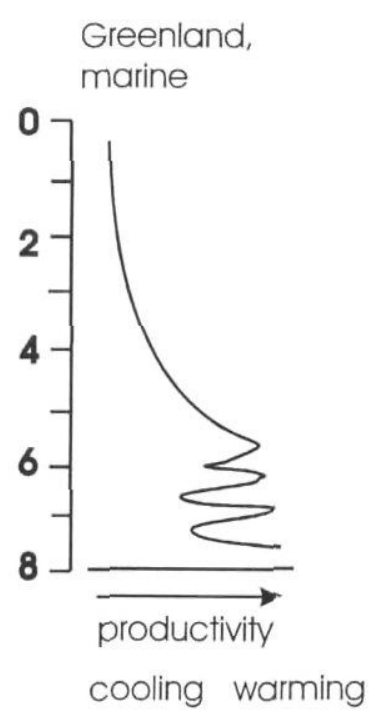

cooling warming
FIGURE 9. Diatom productivity changes in lacustrine and marine environments. Productivity and species changes are used as proxy indicators of cooling and warming. Diagram is a composite and is based on one Labrador lake core (Clark et al., 1989), seven marine cores from along the Baffin Island coast (Williams, 1990) and one marine core from the mid-East Greenland shelf (Williams, 1993). Accumulation, concentration, species changes and chronologic control are discussed in those publications.

Changements dans la productivité des diatomées en milieux lacustre et marin. Les changements dans la productivité et dans les espèces servent d'indicateurs de refroidissement ou de réchauffement. Les diagrammes ont été réalisés à partir du forage d'un lac du Labrador (Clark et al., 1989), de sept forages marins le long de la côte de l'île de Bafffin (Williams, 1990) et d'un forage marin de l'est du Groenland (Williams, 1993). L'accumulation, la concentration, les changements dans les espèces et la chronologie sont expliqués dans ces publications. 
Island, with a warming trend from ca. 7.5 to the onset of neoglaciation around $4.5 \mathrm{ka}$.

However, the marine core record, based on eight cores, from the Baffin Island coast as discussed in Williams (1990a), from Strathcona Sound (Short et al., 1994) in the north and from Frobisher Bay in the south, suggests a different scenario. A time of initial glacial melt prior to 8 or 9 ka is often indicated by a spike in the diatom record, suggested by an enhanced flux of frustules to the sea floor. At ca. $8 \mathrm{ka}$ in the southern to middle Baffin Island coast the diatom productivity is greatly diminished or totally lacking. It returns around 6 or $5 \mathrm{ka}$, perhaps depending on latitude (Fig. 9) (Williams, 1990a).

A similar pattern in diatom productivity is found in two lakes (located very close to the shore) from southernmost Baffin Island, most likely because of changes in lake ice extent (Williams, 1990b). A third lake, from the same immediate area, indicates a productivity increase around 8-6 ka. However, this lake emerged from the sea around $8.4 \mathrm{ka}$, and therefore was influenced by a different set of variables (e.g. inflow of marine water during storm surges, spring tides) than the other two and is therefore not directly comparable (Williams, 1990b).

The marine diatom record from East Greenland, based on analyses of a core transect along the Kangerdlugssuaq trough (Fig. 9), also suggests a major circulation change beginning around 6 or $5.5 \mathrm{ka}$ (Fig. 9). In that region diatom productivity was greatly diminished about 6 ka., and this is probably linked to the Arctic Channels and their isostatic rebound. As less volume of water flowed through the Arctic Channels, a greater volume must have flowed out through the only other exit from the Arctic Ocean, namely the Fram and Denmark Straits, along the east coast of Greenland.
This outflow of cold, low salinity surface water carries with it large volumes of sea ice and ice bergs today, and it probably did in the past. This resulted in decreased diatom productivity as the sea ice extent, spacially and temporally, must have increased, shortening the growing season. Similar events have been recorded in the Greenland/ Iceland Seas during this century, with a concomitant decrease in marine primary productivity (Thordardottir, 1977)

\section{DISCUSSION AND CONCLUSIONS}

Terrestrial warming intensified around 6 ka both in the Labrador-Ungava area and in Baffin Island, as most of the remnants of the ice sheet had disappeared. The glacial melt was in part driven by insolation changes that reached a summer maximum around $10 \mathrm{ka}$ in the northern hemisphere at $65^{\circ} \mathrm{N}$ (e.g. Berger and Loutre, 1991) (Fig. 10). At that time the sediment accumulation records from the fjords indicate a large efflux of glacial meltwater into the marine environment (Fig.10). Subsequently, the middle Holocene saw a decrease of sediment accumulation rates as there were only remnants of the ice sheet left (Andrews, 1990).

Terrestrial warming followed deglaciation of land and lagged the insolation maximum by several thousand years. Thus, the 6 ka maximum occurred about 4000 years after the insolation maximum, the lag response caused by the thermal inertia of the once large ice sheet.

Sediment accumulation records from the fjords demonstrate that the early Holocene was a time of relative warming (compared to earlier), with a large efflux of glacial meltwater into the marine environment (Fig. 10). Subsequently, the middle Holocene saw a decrease of sediment accululation rates as there were only remnants of the ice sheet left (Andrews, 1990).

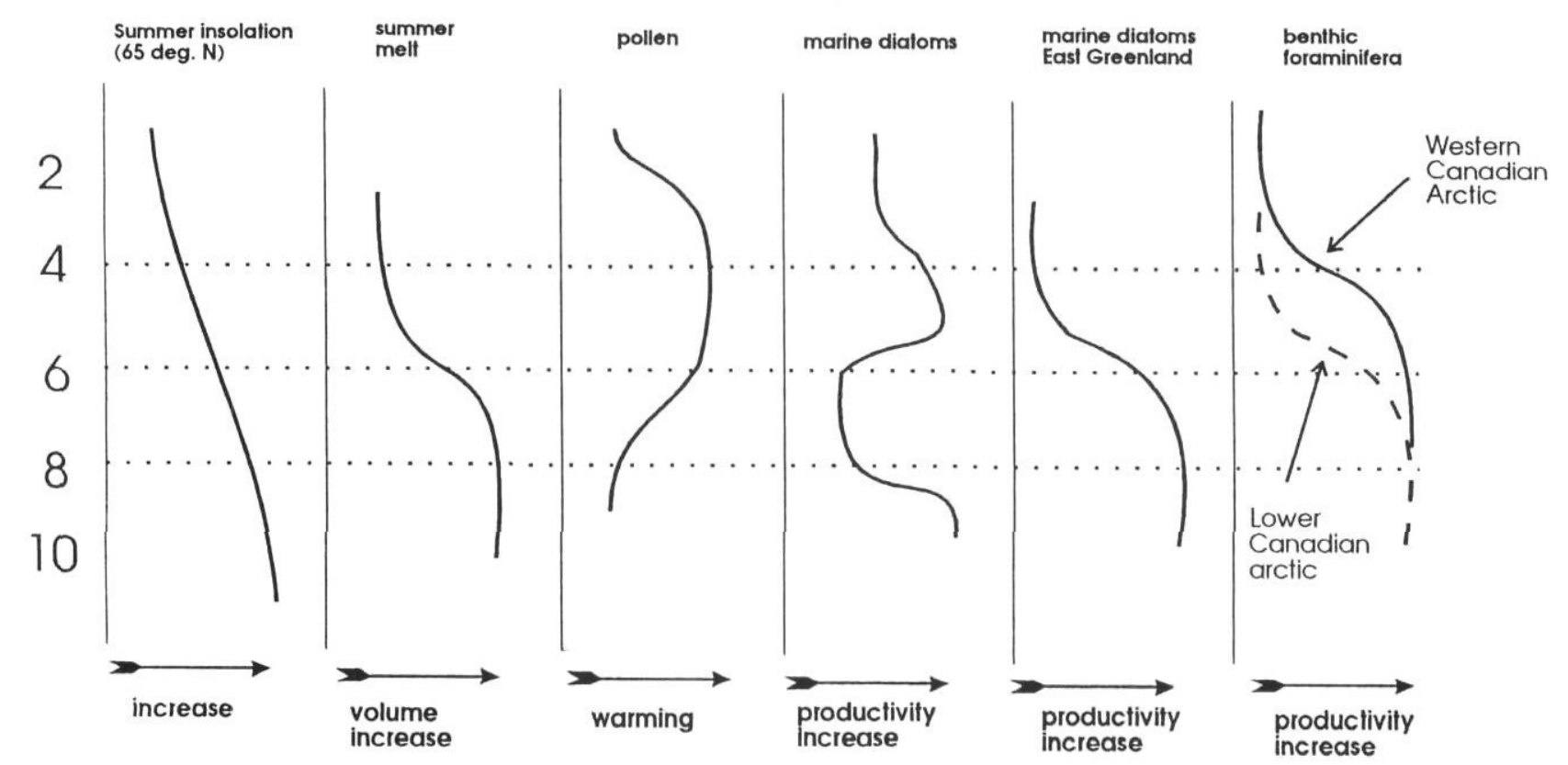

FIGURE 10. Comparison of various proxy indicators used in this paper and the time of change.
Comparaison entre différents indicateurs employés et époques des changements enregistrés. 
The mollusc record is an indicator of near-shore conditions. The relatively shallow water close to shore responds to seasonal warming more readily than off-shore water and can therefore be expected to provide a suitable environment for the subarctic molluscs; in our records this is dated to around 9 to $6 \mathrm{ka}$.

In the Labrador-Ungava region, both the pollen data and the quantitative transfer function analyses of those data indicate that the terrestrial warming, which began by $8 \mathrm{ka}$, intensified around $6 \mathrm{ka}$, leading to a very rich, diverse and productive vegetation. Maximum summer temperatures were maintained in the region until ca. $3 \mathrm{ka}$ (Fig. 10). For this reason, the delay in tree migration into northern LabradorUngava is not well understood. We have hypothesized that it may be due to climatic fluctuations, topographic controls and/or the presence of late-lying ice in the center of the peninsula.

The diatom records from Labrador-Ungava indicate similar temperature changes in that region. Diatom records from Square Lake in the Torngat Mountains, Labrador, suggest a period of relative warmth beginning around $6.5 \mathrm{ka}$ and peaking at around 6 ka only to decrease around $4 \mathrm{ka}$ (Clark et al., 1989) (Fig. 10).

In pollen diagrams from Baffin Island lake sediment cores, birch percentages began to rise around $6 \mathrm{ka}$. Although some of this birch pollen may be exotic (the timing coincides with high birch pollen production in Labrador-Ungava), this rise is interpreted as indicating a range expansion of shrub birch in the region. Decreases in birch percentages after $5 \mathrm{ka}$ and $3 \mathrm{ka}$ indicate contraction of shrub birch's range due to cooling. Rising birch percentages at $6 \mathrm{ka}$, however, while indicative of warmer than present conditions, could have lagged behind the initial warming because of the time required for birch to migrate. High willow percentages that precede the birch rise at $6 \mathrm{ka}$ could indicate that shrub tundra was more widespread than it is today reflecting warmer than present conditions prior to $6 \mathrm{ka}$.

\section{A SCENARIO FOR CHANGES IN THE COASTAL ECOSYSTEMS}

The Arctic channels were deeper during and after deglaciation (ca. $9 \mathrm{ka}$ ) than now (e.g. England, 1976). After

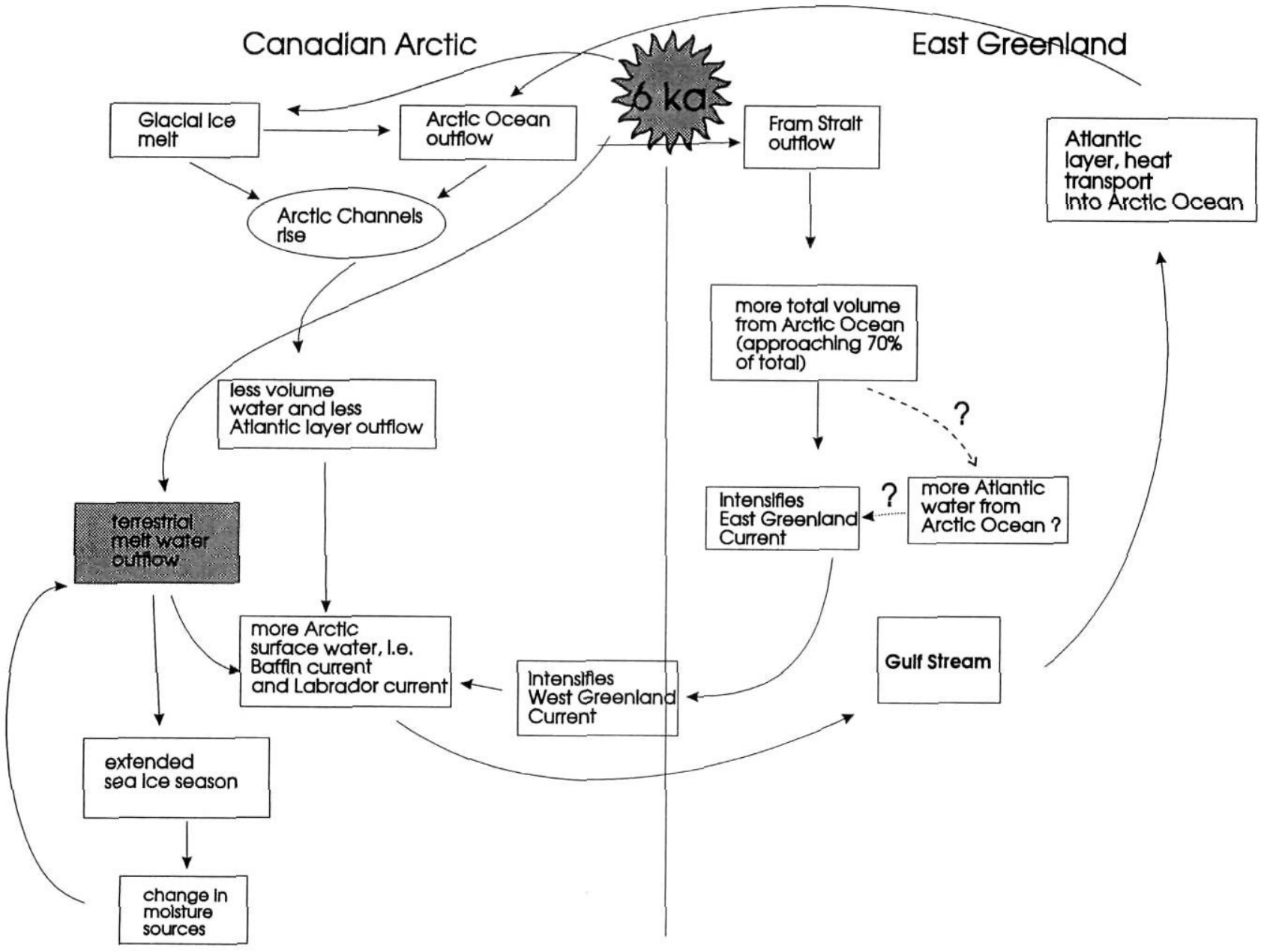

FIGURE 11. Flow diagram showing interaction between variables driving climatic change around middle Holocene.
Diagramme montant les interactions entre les différentes variables responsables des changements climatiques vers le milieu de l'Holocène. 
unloading of the ice sheet, isostatic rebound caused the channels to rise, and around 6 ka the Arctic Channels had probably risen enough to curtail the warmer Atlantic water inflow from the Arctic Ocean into the Canadian Arctic. By 3 ka it had been essentially cut off all together, as indicated by the benthic foraminifera (Fig. 10).

In southern and central Baffin Island, the change from Atlantic "warm" water to Arctic cold water on the continental shelves begins about $6 \mathrm{ka}$. Thus, instead of having an Atlantic water layer entering Baffin Bay and Davis Strait from two directions (Arctic Channels and West Greenland Current), Atlantic water now only came from the West Greenland Current, and would not normally impinge on the Baffin Island continental shelves because the Atlantic layer lay mostly below the continental shelves.

With the shallowing of the Arctic channels, a redistribution of Arctic ocean outflow followed (Fig. 11). Less volume flowed through the channels, with more water exiting along the East Greenland coast through Fram and Denmark straits. The East Greenland Current thus must have gradually intensified, carrying with it at least an increased flow of Arctic surface water, and probably also more of the Atlantic layer. The diatom records from the East Greenland coast indicate an increased outflow of fresh water in the form of sea-ice from the Arctic Ocean beginning around $6 \mathrm{ka}$ (Fig 11) (Williams, 1993). It follows that the West Greenland Current also intensified and contributed both Arctic surface water and Atlantic water. The Atlantic component was deflected, then as it is now, westward and flowed up as bottom water in the deeper troughs such as Frobisher Bay. However, it probably did not reach further north due to the increased total volume (East Greenland Current/West Greenland Current + Baffinland Current) of Arctic surface water now occupying the continental shelves. Benthic foraminifera records suggest strongly that no Atlantic water was present on the shelves, except in Frobisher Bay.

Also, with potential changes in temporal and spatial extent of sea ice comes a probable change in moisture sources, providing a powerful feed-back mechanism for changes in glacier growth and decay. Changing surface current strengths in the BC and Labrador current must also have affected the Gulf Stream intensity, because all the currents in the northern hemisphere can be considered a closed system.

The surface water as recorded by the diatoms presents a different picture. Along the Baffin Island coast the diatom productivity hiatus ( $\mathrm{ca}$. 8-5.5 ka) has been interpreted as a signal of increased meltwater outflow over the coastal areas (Williams, 1990a). This probably was due to the very same conditions that warmed the land and this idea is supported by the increasing sediment accumulation rates recorded from the fjords around that same time (Fig. 11). Land-warming caused the glacial ice to melt increasingly rapidly, flushing out large quantities of fresh, cold (near freezing) meltwater. Meltwater may then have formed a cap of cold, relatively fresh water on top of the marine surface (Williams, 1990a), extending the sea ice season and limiting the time needed for algal growth. Further, the glacial meltwater may have been seasonally turbid, cutting down light transmission necessary for plant life. Dyke (1974) showed that the glacial meltwater outflow in central and northern Baffin Island was at a maximum between 8 and $5.5 \mathrm{ka}$, which corroborates the diatom results.

The following conclusions can be drawn from the data.

1) Sedimentation rates suggest a large efflux of meltwater beginning around $9 \mathrm{ka}$ and lasting through $6 \mathrm{ka}$, in response to, and lagging the summer insolation maximum.

2) Terrestrial records show warming conditions beginning around $8 \mathrm{ka}$ and intensifying at $6 \mathrm{ka}$, both in LabradorUngava and Baffin Island.

3) Marine records indicate major water structure changes around 6 ka both in the Northeastern Canadian Arctic and along the Greenland coast.

4) The marine circulation changes were primarily driven by isostatic uplift of the Arctic Channels.

\section{ACKNOWLEDGEMENTS}

Our sincere thanks to Scott Elias and Nancy Weiner for their generous assistance. This work was funded by NSF grants ATM-9122974, DPP-9296065 and OPP-9224254, which is gratefully acknowledged. This forms Geological Survey of Canada contribution No. 38994. We are grateful to Anne de Vernal and two anonymous reviewers for their useful suggestions.

\section{REFERENCES}

Abbott, M.B., 1991. Radiocarbon dating and interpretation of sediments from five lake systems along Frobisher Bay, N.W.T., Canada. M.Sc. thesis, University of Colorado, Boulder, $237 \mathrm{p}$.

Andrews, J.T., 1972. Recent and fossil growth rates of marine bivalves, Canadian Arctic, and Late-Quaternary Arctic marine environments. Palaeogeography, Palaeclimatology, Palaeoecology, 11: 157-176.

1980. Progress in relative sea level and ice sheet reconstructions, Baffin Island, N.W.T., for the last 125,000 years., p. 275-300. In N.-A. Mörner, ed., Earth rheology, isostasy and eustasy. Wiley \& Sons, London.

- 1982. Chronostratigraphic division of the Holocene, Arctic Canada. Striae, 16: 56-64.

1985. Reconstruction of environmental conditions in the eastern Canadian arctic during the last 11,000 years, p. 423-451. In C.R. Harington, ed., Climatic Change in Canada 5 - Critical Periods in the Quaternary Climatic History of Northern North America. National Museum of Natural Sciences Project on Climatic Change in Canada During the Past 20,000 years. Ottawa, National Museums of Canada, Syllogeus, 55 .

1987. The late Wisconsin Glaciation and deglaciation of the Laurentide Ice Sheet, p. 13-37. In W.F. Ruddiman and H.E.J. Wright, eds., North America and adjacent oceans during the last deglaciation. Geological Society of America.

1989. Quaternary of the northeastern Canadian Shield, p. 543-572. In R.J. Fulton, ed., Quaternary geology of Canada and Greenland. Geological Survey of Canada, Geology of Canada, no. 1 (also Geological Society of America, The Geology of North America, v. K-1).

- 1990. Fiord to deep sea sediment transfers along the northeastern Canadian continental margin: models and data. Géographie physique et Quaternaire, 44:55-70. 
Andrews, J.T., Mode, W.N. and Davis, P.T., 1980. Holocene climate based on pollen transfer functions, eastern Canadian Arctic. Arctic and Alpine Research, 12:41-64.

Andrews, J.T. and Miller, G.H., 1972. Quaternary history of northern Cumberland Peninsula, Baffin Island, N.W.T., Canada: Part IV: Maps of the present glaciation limits and lowest equilibrium line altitude for north and south Baffin Island. Arctic and Alpine Research, 4(1): 45-59.

Andrews, J.T., Davis, P.T., Mode, W.N., Nichols, H. and Short, S.K., 1981. Relative departure in July temperatures in northern Canada for the past 6,000 yr. Nature, 289:164-167.

Andrews, J.T., Osterman, L.E. and Kravitz, J., 1984. Quaternary studies on Baffin Island fiord cores. In J.P.M. Syvitski, ed., Sedimentology of Arctic Fjords Experiment: Hu 83-028 Data Report, Volume 2. Canadian Data Report of Hydrography and Ocean Sciences, No. 28: chapter 15.

Andrews, J.T. and Peltier, W.R., 1989. Quaternary Geodynamics in Canada, p. 543-572. In Fulton, R.J., ed., Quaternary Geology of Canada and Greenland, Geological Survey of Canada, Geology of Canada, no. 1 (also Geological Society of America, The Geology of North America, v. $\mathrm{K}-1)$.

Andrews, J.T., Jennings, A.E., Miller, G.H., Williams, K.M., Syvitski, J.P.M., Osterman, L.E. and Mode, W.N., 1994. A younger Dryas age event (?) and paleoclimatic conditions based on an estuarine (fiord) core, Sunneshine Fiord, E. Baffin Island. GSA abstracts, fall meeting, Oct. 1994.

Bard, E., Arnold, M., Fairbanks, R.G. and Hamelin, B., 1993. ${ }^{230} \mathrm{Th}-{ }^{234} \mathrm{U}$ and ${ }^{14} \mathrm{C}$ ages obtained by mass spectrometry on corals. Radiocarbon, 35 : 191-200.

Berger, A. and Loutre, M.F., 1991. Insolation values for the climate of the last 10 million years. Quaternary Science Review, 10: 297-317.

Clark, P.U., Short, S.K., Williams, K.M. and Andrews, J.T. 1989. Late Quaternary chronology and environments of Square Lake, Torngat Mountains, Labrador. Canadian Journal of Earth Sciences, 26: 21302144.

Davis, P.T., 1980. Late Holocene glacial, vegetational, and climatic history of Pangnirtung and Kingnait Fiord area, Baffin Island, Canada. Ph.D. dissertation, University of Colorado, Boulder, $366 \mathrm{p}$.

Diaz, H.F., 1985. A comparison of twentieth century climatic anomalies in northern North America with reconstructed patterns of temperature and precipitation based on pollen and tree-ring data. Ph.D. dissertation, University of Colorado, Boulder, $234 \mathrm{p}$.

Diaz, H.F, Andrews, J.T. and Short, S.K., 1989. Climate variations in northern North America (6000 BP to present) reconstructed from pollen and tree-ring data. Arctic and Alpine Research, 21: 45-59.

Dyke, A., 1974. Deglacial chronology and uplift history: Northeastern sector, Laurentide Ice Sheet. Occasional Paper No. 12, Institute of Arctic and Alpine Research, University of Colorado, Boulder, $113 \mathrm{p}$.

Dyke, A.S. and Prest, V.K., 1987. Late Wisconsinan and Holocene history of the Laurentide Ice Sheet. Géographie physique et Quaternaire, 41: 237-263.

England, J., 1976. Postglacial isobases and uplift curves from the Canadian and Greenland High Arctic. Arctic and Alpine Research, 8 (1): 61 . 78.

Funder, S. and Weidick, A., 1991. Holocene boreal molluscs in Greenland: Paleocanographic implications. Paleogeography, Paleoclimatology. Paleoecology, 85: 123-135.

Hillaire-Marcel, C., De Vernal, A., Aksu, A.S. and Macko, S., 1989. Highresolution isotopic and micropaleontological studies of upper Pleistocene sediments at ODP site 645, Baffin Bay, p. 599-616. In S.P. Srivastava, M.A. Arthur, B. Clement et al., Proceedings of the Ocean Drilling Program, Scientific Results. Vol. 105, College station, TX (Ocean Drilling Program).

Hunt, A.S. and Corliss, B.N., 1993. Distribution and microhabitats of living (stained) benthic formanifera from the Canadian Arctic Archipelago. Marine Micropaleontology, 20: 321-345.

Imbrie, J. and Kipp, N.G., 1971. A new micropaleontological method for quantitative paleoclimatology: Application to a late Pleistocene Carib- bean core, p. 71-81. In K.K. Turekian, ed., The Late Cenozoic Glacial Age. Yale University Press, New Haven.

Jacobs, J.D., Andrews, J.T. and Funder, S., 1985. Environmental Background, p. 26-68. In J.T. Andrews, ed., Quaternary Environments: Eastern Canadian Arctic, Baffin Bay and Western Greenland. Allen and Unwin, Boston, 774 p.

Jennings, A.E., 1989. Late Quaternary history of Cumberland Sound, Baffin Island, Arctic Canada. Ph.D. thesis, University of Colorado, Boulder, $319 \mathrm{p}$.

Kay, P.A. and Andrews, J.T., 1983. Re-evaluation of pollen-climate transfer functions in Keewatin, northern Canada. Annals of the Association of American Geographers, 73: 550-559.

Lemmen, D.S., Gilbert, R., Smol, J.P. and Hall, R.I., 1988. Holocene sedimentation in glacial Tasikutaaq Lake, Baffin Island. Canadian Journal of Earth Sciences, 25: 810-823.

Lubinsky, I., 1972. The marine bivalve molluscs of the Canadian Arctic. Ph.D. thesis, McGill University, Montréal, 318 p.

MacLean, B., Sonnichsen, G., Vilks, G., Powell, C, Moran, K., Jennings, A., Hodgson, D. and Deonarine, B., 1989. Marine geological and geotechnical investigations in Wellington, Byam Martin, Austin, and adjacent channels, Canadian Arctic Archipelago. Geological Survey of Canada paper 89-11, $69 \mathrm{p}$.

Maxwell, J.B., 1981. Climatic regions of the Canadian Arctic Islands. Arctic, 34: $225-240$.

Miller, G.H., 1980. Late Foxe Glaciation of southern Baffin Island, N.W.T., Canada. Geological Society of America Bulletin, 91: 399-405

Miller, R.J.O., 1992. Late Quaternary lacustrine paleoenvironmental records from southeast Baffin Island, N.W.T., Canada. Ph.D. thesis, University of Colorado, Boulder, $296 \mathrm{p}$.

Mode, W.N., 1980. Quaternary stratigraphy and palynology of Clyde Foreland, Baffin Island, N.W.T., Canada. Ph.D. dissertation, University of Colorado, Boulder, $219 \mathrm{p}$.

Mode, W.N. and Jacobs, J.D., 1987. Surficial geology and palynology, inner Frobisher Bay, p. 53-62. In J.T. Andrews, R. Gilbert, J.D. Jacobs, G.H. Miller, W.N. Mode and J.D. Stravers, eds., Cumberland Sound and Frobisher Bay, southeastern Baffin Island, Northwest Territories. XIlth INQUA, Congress Field Excursion C-2 Guidebook. National Research Council of Canada, Ottawa.

Mudie, P.J. and Short, S.K., 1985. Marine palynology of Baffin Bay, p. 263308. In J.T. Andrews, ed., Quaternary environments: Eastern Canadian Arctic, Baffin Bay and western Greenland. Allen and Unwin, Boston, $774 \mathrm{p}$.

Osterman, L.E., 1984. Benthic foraminiferal zonation of a glacial/interglacial transition from Frobisher Bay, Baffin Island, Northwest Territories, Canada, p. 471-476. In Benthos '83, 2nd International Symposium on Benthic Foraminifera (Pau, April 1983).

Osterman, L.E. and Nelson, A.R., 1989. Latest Quaternary and Holocene paleoceanography of the eastern Baffin Island continental shelf, Canada: Benthic foraminiferal evidence. Canadian Journal of Earth Sciences, 26: 2236-2248.

Quinlan, G., 1985. A numerical model of postglacial relative sea level change near Baffin Island, p. 560-584. In J.T. Andrews, ed., Quaternary Environments: Eastern Canadian Arctic, Baffin Bay and Western Greenland. Allen and Unwin, Boston, $774 \mathrm{p}$.

Short, S.K., 1978. Holocene palynology in Labrador-Ungava: Climatic history and culture change on the central coast. Ph.D. dissertation, University of Colorado, Boulder, $231 \mathrm{p}$.

_ 1978. Palynology: A Holocene environmental perspective for archeology in Labrador - Ungava. Arctic Anthropology, 25, 9-35.

Short, S.K., Mode, W.N. and Davis, P.T., 1985. The Holocene record from Baffin Island: Modern and fossil pollen studies, p. 608-642. In J.T. Andrews, ed., Quaternary environments: Eastern Canadian Arctic, Baffin Bay, and western Greenland. Allen and Unwin, Boston, 774 p. 
Short, S.K. and Nichols, H., 1977. Palynology: A Holocene environmental perspective for archaeolology in Labrador-Ungava. Arctic Anthropology, 15: 9-35.

Short, S.K., Andrews, J.T. and Mode, W.N., 1989. Modern and late Quaternary pollen spectra of fiord sediments, eastern Baffin Island, Arctic Canada. Marine Micropaleontology, 15: 181-202.

Short, S.K., Andrews, J.T., William, K.M., Weiner, N.J. and Elias, S.A., 1994. Late Quaternary marine and terrestrial environments, northwestern Baffin Island, N.W.T., Canada. Géographie physique et Quaternaire, 48: 85-95.

Stravers, L.K., 1981. Palynology and deglaciation history of the central Labrador-Ungava peninsula. M.Sc. thesis, University of Colorado, Boulder, $171 \mathrm{p}$.

Stuiver, M. and Braziunas, T.F., 1993. Modeling atmospheric ${ }^{14} \mathrm{C}$ influences and ${ }^{14} \mathrm{C}$ ages of marine samples to $10,000 \mathrm{BC}$. Radiocarbon, 35: 137 . 190.

Stuiver, M. and Reimer, P.J., 1993. Extended ${ }^{14} \mathrm{C}$ data base and revised Calib 3.0 age calibration program. Radiocarbon, 35: 215-230.

Syvitski, J.P.M. and Hein, F.J., 1991. Sedimentology of an arctic basin Itirbilung Fiord, Baffin Island, Canada. Geological Survey of Canada Professional Paper 91-11, 67.

Syvitski, J.P.M., LeBlanc, K.W.G. and Cranston, R.E., 1990. The flux and preservation of organic carbon in Baffin Island fjords, p. 177-199. In J.A. Dowdeswell and J.D. Scourse, eds., Glacimarine environments: Processes and products. Geological Society Special Publication, No. 53.

Syvitski, J.P.M. and Andrews, J.T., 1994. Global change: Numerical modelling in sedimentation and coastal processes, Eastern Canadian Arctic. Arctic and Alpine Research, 26:199-212.
Thordardottir, T., 1977. Primary production in North Icelandic waters in relation to recent climatic changes, p. 655-665. In M.J. Dunbar, ed., Polar Oceans. Arctic Institute of North America, Calgary.

Vilks, G., 1969. Recent foraminifera in the Canadian Arctic. Micropaleontology, 15: 35-60.

Vilks, G., MacLean, B., Deonarine, B., Currie, C.G. and Moran, K., 1989. Late Quaternary paleoceanography and sedimentary environments in Hudson Strait. Géographie physique et Quaternaire, 43: 161-178.

Webb, T. and Bryson, R.A., 1972. Late- and post-glacial climatic change in northern Midwest, U.S.A.: Quantitative estimates derived from fossil pollen spectra by multivariate statistical analysis. Quaternary Research, 2: $70-115$

Williams, L.D. and Bradley, R.S., 1985. Paleoclimatology of the Baffin Bay Region, p. 741-772. In J.T. Andrews, ed., Quaternary environments: Eastern Canadian Arctic, Baffin Bay, and western Greenland. Allen and Unwin, Boston, $774 \mathrm{p}$.

Williams, K.M., 1990a. Late Quaternary paleoceanography of the western Baffin Bay region: evidence from fossil diatoms. Canadian Journal of Earth Sciences, 27: 1487-1494.

- 1990b. Paleolimnology of three Jackman Sound Lakes, Southern Baffin Island, based on down-core diatom analyses. Journal of Paleolimnology, 4: 203-217.

1993. Ice sheet and ocean interactions, margin of the East Greenland ice sheet (14 ka to present): Diatom evidence. Paleoceanography, 8: 69-83.

Winters, G.V. and Syvitski, J.P.M., 1992. Suspended sediment character and distribution in MacBeth Fiord, Baffin Island. Arctic 45: 25-35. 